\title{
Effect of phosphorus levels and phosphate solubilizing bacteria on growth and seed production in coriander
}

\author{
Faryal Idrees ${ }^{1 *}$, Gohar Ayub ${ }^{1}$, Sidra Saleem ${ }^{1}$ and Seema Zubair $^{2}$ \\ 1. Department of Horticulture, The University of Agriculture Peshawar-Pakistan \\ 2. Department of Maths State and Computer Science, The University of Agriculture Peshawar-Pakistan \\ *Corresponding author's email: faryalmohmond457@gmail.com \\ Citation
}

Faryal Idrees, Gohar Ayub, Sidra Saleem and Seema Zubair. Effect of phosphorus levels and phosphate solubilizing bacteria on growth and seed production in coriander. Pure and Applied Biology. Vol. 10, Issue 3, pp617-627. http://dx.doi.org/10.19045/bspab.2021.100063

\begin{tabular}{llll}
\hline \hline Received: 20/08/2020 & Revised: 26/10/2020 & Accepted: 03/11/2020 & Online First: 19/11/2020 \\
\hline \hline
\end{tabular}

Abstract

A field trial on "Effect of phosphorus levels and phosphate solubilizing bacteria (PSB) on growth and seed production in coriander" was performed at Horticulture Research Farm, The University of Agriculture Peshawar, Pakistan during 2016-17. The research was carried out using Randomized complete block design (RCBD) with split plot arrangement, having two factors repeated three times. Different Phosphorus (P) levels (0, 20, 40, 60 and $\left.80 \mathrm{~kg} \mathrm{ha}^{-1}\right)$ were used along with and without phosphate solubilizing bacteria (PSB). Different levels of (P) and (PSB) showed significant effects on all growth parameters except days to emergence. The interaction effect of the treatments was nonsignificant for most of the parameters with the exception of days to flowering, seed yield plant ${ }^{-1}$ and seed yield $\mathrm{ha}^{-1}$. Early flowering (95.4 days), maximum plant height $(122.3 \mathrm{~cm})$, minimum days to maturity (132.3), maximum number of umbel plant $^{-1}(41.8)$, number of umbellate umbel ${ }^{-1}(8.5)$, number of seeds umbellate ${ }^{-1}(8.3), 1000$ seed weight $(11.4 \mathrm{~g})$ and maximum seed yield ha-1 $(1212 \mathrm{~kg})$ were recorded with P @ $40 \mathrm{~kg} \mathrm{ha}^{-1}$. Similarly PSB treatment caused early flowering (101.5 days), maximum plant height $(114.9 \mathrm{~cm})$, minimum days to maturity (139.5), maximum number of umbel plant $^{-1}(36.5)$, number of umbellate umbel ${ }^{-1}(7)$, number of seeds umbellate ${ }^{-1}(7.8), 1000$ seed weight $(10.3 \mathrm{~g})$ and seed yield ha-1 $(1105 \mathrm{~kg})$. Thus, phosphorus @ $40 \mathrm{~kg} \mathrm{ha}^{-1}$ along with phosphate solubilizing bacteria were found as influencing factors for the studied attributes and, hence can be effectively used for improved growth and higher seed yield of coriander.

Keywords: Bio fertilizer; Coriandrum sativum; Growth; Inorganic fertilizer; Seed yield

\section{Introduction}

Coriander (Coriandrum sativum L.), member of the family "Apiaceae" and native crop of the Mediterranean region is grown mostly in Italy, India, Morocco, Central Europe, Pakistan, Bangladesh, Russia and China [1] The seeds and foliage of this spice are commonly used for different food applications and essential oil extraction [2]. The worldwide production of coriander seed is estimated to be approximately 6 lakh tones. In Pakistan, area under coriander cultivation is 5.9 "O00ha", while production is 2.6 "000ton"
[3]. Coriander is an aromatic plant, mostly cultivated as a winter or summer annual crop. It is a tender plant, having more or less erect stem with height reaching up to $140 \mathrm{~cm}$, depending upon variety [4]. Coriander plant is characterized with tap roots and the flowering stalk consists of variably shaped leaves, which are broadly lobbed at the base and slightly slender and feathery at top of the stalk. The inflorescence of this plant is a compound umbel with appearance of white or pale pink flowers on the primary umbel. 
Coriander is photo sensitive and an increase in day length trigger flowering. Honey bees are the source of pollination in coriander [5]. The small globular or ovate fruits have a diameter of 3 to $5 \mathrm{~mm}$ and referred as coriander seeds upon drying. On the basis of seeds, coriander has two varieties; the small seeded variety, which is grown widely for essential oil production and large seeded variety for whole seeds. Coriander performs well in tropical and subtropical climate. It can be grown on a wide range of soils, but well drained and fine textured soil gives best result. Coriander requires an optimum $\mathrm{pH}$ of 6.3 and growing temperature of $18^{\circ} \mathrm{C}[6]$. The small seeded coriander plants require more days to maturity, while large seeded plants mature earlier. The chemical composition of coriander seeds made it an important spice and medicinal crop. Essential oil is good against bacterial infection and cancer, furthermore; having an antioxidant and antimutagenic properties [7]. In addition to pharmaceutical properties, coriander essential oil is also an important constitue nt of cosmetics, lotions, soaps, creams, detergents and shampoo; as giving a characteristic smell to the products [1]. Coriander leaves provides sufficient amount of vitamin (A, C and K), folate and minerals like calcium, iron, potassium, manganese, along with a fair amount of dietary fibers. Appropriate amount of fertilizers play a key role in production of healthy plants, which gives good number of shoots, flowers and foliage, consequences a good effect on quality seed production. For the production of vigorous plants, nitrogen, phosphorus and potassium plays significant role in term of maximum flower production and seed yield of crops [8]. Low and imbalance nutrient status of the soil results in lower productivity and ultimately become a main risk to sustain soil physical condition and crop productivity. Phosphorus performs a significant function in plant life and is thought to be a key element for numerous functions like fruit formation and ripening, carbohydrates translocation along with protein synthesis [9]. Phosphorus is involved in energy transfer reaction. It also helps in photosynthesis, respiration and nutrient movements. Phosphorus is found to be a part of several enzymes. Phosphorus fertilization induce early flowering and it hastens maturity. Phosphorus is also responsible for seed formation and root development. With addition to soil as inorganic phosphates, a huge fraction of soluble inorganic phosphate becomes unavailable to plants due to immobilization. Out of 100 , only 20 percent phosphorus is available for the plant growth and development. Availability of phosphorus may be affected due to soil $\mathrm{pH}$, texture and moisture, calcium concentration, proportion of clay and organic matter. Phosphorus availability reduces as soil $\mathrm{pH}$ increases. Lack of Phosphorus is the most vital feature, limiting plant development. Bio fertilizers are currently gaining extra attention in the background of sustainable agriculture. This is a result of the need to solve health and ecological problems caused by the extreme use of agrochemicals in conventional cultivation. Bio fertilizers have the potential to alter nutritionally significant elements from unavailable to available form through organic processes. Bio fertilizers are cheap, eco-friendly and sustainable. Providing phosphorus to the plants through natural way is a vital replacement, because phosphate solubilizing bacteria (PSB) helps in insoluble phosphates conversion to soluble ions. The main mechanism of phosphate solubilizing bacteria is the lowering of soil $\mathrm{pH}$ by releasing certain organic acids. Thus, acidification of the surrounding soil results in releasing orthophosphate ions. These orthophosphate ions can easily be taken up by the plants [10]. Soil microbes have higher ability to ensure availability of soil phosphates for plant development. These microbes improve soil health by increasing soil porosity. Furthermore, microbes concerned in Phosphorus solubilization can improve growth of many plants fixation of 
nitrogen, promoting accessibility of other vital elements [11]. The purpose of the current study was to evaluate the effect of phosphorus levels and phosphate solubilizing bacteria on growth and seed production in coriander.

\section{Materials and Methods}

The experiment "Effect of phosphorus levels and phosphate solubilizing bacteria (PSB) on growth and seed production in coriander" was evaluated at Horticulture

Research Farm, The University of Agriculture Peshawar, Pakistan in 2016-17. RCBD with split plot arrangement was used, having two factors repeated three times. Coriander cultivar "Dilpazer" was used as study material. Before fertilizer application soil samples were analyzed in the Laboratory. Result of the analysis is given in the (Table 1).

Table 1. Physio-chemical properties of the experimental plot

\begin{tabular}{|c|c|c|}
\hline Properties & Units & Value \\
\hline Soil Texture & & Silt loam \\
\hline Organic matter content & $\%$ & 1.06 \\
\hline Soil pH & $\%$ & 8.2 \\
\hline Total Nitrogen & $\mathrm{mg} \mathrm{kg}^{-1}$ & 0.011 \\
\hline AB-DTPA extractable phosphorus & & 13.16 \\
\hline
\end{tabular}

\section{Soil preparation}

The soil was ploughed twice and then leveled. Seed beds were prepared. Row to row and plant to plant distances were kept 30 and $25 \mathrm{~cm}$ respectively. The plot size used was $0.9 \mathrm{~m} \mathrm{x} 1.25 \mathrm{~m}$ (plot area $=1.125$ $\mathrm{m}^{2}$ ). Coriander seeds were treated with bio fertilizer solution before sowing. PSB (Pseudomonas striata) was used as bio fertilizer at the rate of $2.5 \mathrm{~kg} \mathrm{ha}^{-1}$. Phosphate solubilizing bacteria contains $1 \times 10^{8}$ bacterial cells $\mathrm{kg}^{-1}$. All cultural practices were carried out uniformly for all treatments throughout the experimental period. A uniform fertilizer dose of Nitrogen and Potash at the rate of 80 and 25 $\mathrm{kg} \mathrm{ha}^{-1}$ were applied to the experimental field. Full dose of phosphorus and potash and half dose of nitrogen were applied before sowing, while the remaining half nitrogen was applied after $100 \%$ germination of the seeds.

\section{Statistical analysis}

Data obtained on various parameters were analyzed by Statistics 8.1 while LSD test with $5 \%$ probability level was used for means comparison and SigmaPlot (ver: 10.0) was used for graphical presentation.

\section{Results and Discussion}

Days to emergence, days to flowering, plant height, days to maturity, number of umbels plant ${ }^{-1}$

The analysis of variance showed nonsignificant effect of different phosphorus levels, Phosphate solubilizing bacteria (PSB) and their interaction on days to emergence (Table 2), however maximum days to emergence (20.1) were taken in without PSB treatment, while minimum days to emergence (18.0) were recorded in seeds inoculated with PSB (Fig. 1a). Among phosphorus levels maximum days to emergence (20.2) was recorded with the application of phosphorus@80 kg ha-1 and minimum (17.9) days were recorded at control (Fig. 2a).

Concerning days to flower the application of phosphorus and phosphate solubilizing bacteria and their interaction showed significant effect in coriander. Regarding PSB, minimum days to flowering (101.5) were taken by the plants inoculated with PSB and to induce 50\% flowers, whereas maximum days (106.5) were taken by the plants in without PSB (Fig.1a). Among phosphorus levels, minimum number of days to umbel appearance (95.4) was noticed in plants fertilized with $40 \mathrm{~kg} \mathrm{P} \mathrm{Pa}^{-}$ 1 , while maximum number of days (111) was recorded in control plots (Fig. 2a). 
Table 2. The Influence of phosphate solubilizing bacteria and phosphorus fertilization on growth and seed yield of coriander

\begin{tabular}{|c|c|c|c|c|c|c|c|c|c|c|c|}
\hline \multirow{2}{*}{ SOV } & \multirow{2}{*}{ DF } & \multirow{2}{*}{ DTE } & \multirow{2}{*}{ DTF } & \multirow{2}{*}{$\mathbf{p H}$} & \multicolumn{7}{|c|}{ MS } \\
\cline { 6 - 13 } & & & & & DTM & NOUP & NOUU & NOSU & SYP & 1000SW & SYha \\
\hline Rep & 2 & $2.238^{\mathrm{NS}}$ & $1.084^{\mathrm{NS}}$ & $2.0259^{\mathrm{NS}}$ & $0.0663^{\mathrm{NS}}$ & $6.2423^{\mathrm{NS}}$ & $0.0023^{\mathrm{NS}}$ & $0.0688^{\mathrm{NS}}$ & $0.0612^{\mathrm{NS}}$ & $0.1603^{\mathrm{NS}}$ & $1199.04^{\mathrm{NS}}$ \\
\hline PSB & 1 & $34.133^{*}$ & $186.00^{*}$ & $62.582^{*}$ & $170.408^{*}$ & $195.07^{*}$ & $10.443^{*}$ & $25.007^{*}$ & $1.860^{*}$ & $2.8706^{*}$ & $33378.01^{*}$ \\
\hline Error I & 2 & 2.228 & 2.749 & 3.293 & 2.4563 & 5.329 & 0.079 & 0.178 & 0.0297 & 0.1026 & 442.34 \\
\hline P & 4 & $3.748^{\mathrm{NS}}$ & $258.61^{*}$ & $418.62^{*}$ & $355.97^{*}$ & $191.53^{*}$ & $16.347^{*}$ & $9.3368^{*}$ & $3.8052^{*}$ & $6.5096^{*}$ & $67520.4^{*}$ \\
\hline PSBxP & 4 & $2.466^{\mathrm{NS}}$ & $45.010^{*}$ & $4.955^{\mathrm{NS}}$ & $7.5958^{\mathrm{NS}}$ & $0.5283^{\mathrm{NS}}$ & $0.0563^{\mathrm{NS}}$ & $0.1568^{\mathrm{NS}}$ & $0.1021^{*}$ & $0.4864^{\mathrm{NS}}$ & $1968.59^{*}$ \\
\hline Error II & 16 & 1.622 & 5.932 & 10.146 & 3.771 & 4.4985 & 0.1931 & 0.2374 & 0.0335 & 0.2453 & 618.54 \\
\hline Total & 29 & & & & & & & & & & \\
\hline
\end{tabular}

DTE: Days to emergence; DTF: Days to flowering; PH: Plant height (cm); DTM: Days to maturity; NOUP: Number of umbels plant ${ }^{-1}$; NOUU: Number of umbellate umbel ${ }^{-1}$; NOSU: Number of seeds umbellate ${ }^{-1}$; SYP: Seed yield plant ${ }^{-1} ; 1000 \mathrm{SW}$ : 1000 seed weight $(\mathrm{g})$; SYha: Seed yield $\mathrm{ha}^{-1}$.*significant at $\mathrm{p}=0.05$; NS: non-significant; PSB: Phosphate solubilizing bacteria; P: Phosphorus; MS: mean square values 
With the interaction of phosphorus and PSB, minimum days (90.7) were taken by the plants supplied with $40 \mathrm{~kg} \mathrm{P}^{-1}$ along with PSB inoculation. On the other hand maximum number of days (112.8) was taken at control in without PSB (Fig. 3a).

According to mean square values, differe nt phosphorus levels and phosphate solubilizing bacteria showed significant effect to the plant height in coriander, while their interactive effect was found nonsignificant. Comparing means of PSB revealed that maximum height $(114.9 \mathrm{~cm})$ was measured in plants whose seeds were inoculated with phosphate solubilizing bacteria, while minimum plant height $(111.4 \mathrm{~cm})$ was noticed in without PSB (Fig. 1a). Means related to phosphorus showed that maximum plant height (122.3 cm) was recorded with phosphorus@ @ $40 \mathrm{~kg}$ ha $^{-1}$, which gradually decreased with increase in the level of phosphorus and minimum height $(102.3 \mathrm{~cm})$ was recorded in control plots (Fig. 2a)

Data pertaining days to maturity revealed a positive effect of phosphorus and phosphate solubilizing bacteria towards days to maturity, while a non-significant interactive effect. In this regard the maximum days to maturity (144.3) were taken by the plants in without PSB, while minimum days (139.5) were taken by the plants with PSB treatment (Fig. 1a). Among phosphorus levels maximum days to maturity (150.4) were recorded at control, while at $40 \mathrm{~kg} \mathrm{P}$ $\mathrm{ha}^{-1}$, plants took less number of days (132.3) and mature earlier (Fig. 2a).

The number of umbels plant $^{-1}$ in coriander significantly influenced by the treatments; however the interaction of treatments was found non-significant. In this regard maximum number of umbels plant $^{-1}$ (36.5) was examined with phosphate solubilizing bacteria, while minimum number of umbels plant $^{-1}$ (31.4) was noticed in without PSB treatment (Fig. 1b). Means regarding phosphorus showed that maximum number of umbels (41.8) was noticed in plants fertilized with $\mathrm{P}$ at the rate of $40 \mathrm{~kg} \mathrm{ha}^{-1}$, while minimum number of umbels plant ${ }^{-1}$ (28.3) was observed at control (Fig. 2b).

[12] Evaluated the effect of NPK on different growth parameters of coriander and found that coriander emergence was not affected by phosphorus levels. Similarly [13] also found a non-significant effect of phosphorus on coriander germination while studying the effect of phosphorus on coriander. [14] Studied bio fertilizers effect on growth and yield characteristics of coriander and found a non-significant effect of PSB on emergence of coriander seeds. Several factors like seed viability, seed sowing depth, soil temperature and its moisture content and fine tilt etc., also play an important role in seed germination and emergence that is why phosphorus and PSB could not play a significant role in enhancing emergence rate of coriander.

[6] Observed that minimum days to flowering were taken by coriander plants when treated with phosphate solubilizing microorganisms. [14] Found that plants inoculated with phosphate solubilizing bacteria took minimum number of days to flowering as compared to nitrogen fixing bacteria and control. Phosphorus has a significant role in flower development. Uptake and better utilization of optimum amount of phosphorus might result in early flowering. Similar results were obtained by [15]. Plants treated with bio fertilizers like PSB become physiologically more active and enable to synthesize some phytohormones like IAA and cytokinin. These growth promoters were somewhat involved in initiation of floral buds.

[16] Stated that PSB has the ability to increase growth of the plants by ensuring availability of nitrogen through biological nitrogen fixation (BNF). [17] Observed that inoculating coriander seeds with phosphate solubilizer caused considerable increase in vegetative growth of coriander plants. These results are supported by [18] Increase in plant height with maximum dose of phosphorus might be due to the reason that phosphorus is involved in cell division and 
enlargement. Phosphorus fertilization increases the rate of photosynthesis, which ultimately help the plants gaining maximum height. In the presence of bio fertilizer, the plants were able to take more phosphorus from the soil to reach maximum height.

[15] Recorded that plants took less number of days for umbel appearance and maturity with optimal amount of phosphorus fertilization. Phosphorus in soils became less soluble [19] only 20 percent phosphorus is available to the plants and remaining is the insoluble inorganic form of phosphorus that plants cannot absorb. Bio fertilizers like PSB ensure the availability of phosphorus and convert insoluble form to soluble orthophosphate ions. [6] Observed that bio fertilizers significantly reduced days to flowering and maturity.

In line to our results [20] Found that phosphate solubilizing microorganisms significantly influenced the number of umbels plant ${ }^{-1}$ over control. [21] Also reported that number of umbels plant $^{-1}$ was higher with bio fertilizer over control. [22] Examined that phosphorus and nitrogen had a positive effect on number of umbels plant1 . The maximum number of umbels plant ${ }^{-1}$ in coriander could be due to the function of phosphorus in flower formation and development. Phosphorus also promotes root formation and growth, so coriander plants might absorb more nutrients with better root system to produce more number of umbels. [23] Stated that some trace elements are deficient in alkaline soils due to its insoluble form. These bacteria lower the $\mathrm{pH}$ of the soil by releasing certain acids, thus ensuring the availability of essential micronutrients for the plants to produce more flowers.

Number of umbellate umbel ${ }^{-1}$, number of seeds umbellate ${ }^{-1}$, seed yield plant ${ }^{-1}, 1000$ seed weight, seed yield ha-1

PSB showed a positive impact towards number of umbellate umbel $^{-1}$ (Table 2). The maximum number of umbellate umbel $^{-1}$ (7.0) was noticed in plants whose seeds were inoculated with PSB, while minimum number of Umbellate (5.8) was recorded in without PSB (Fig. 1b). In concern of P, maximum number of umbellate umbel $^{-1}$ (8.5) was recorded with $40 \mathrm{~kg} \mathrm{P} \mathrm{ha}^{-1}$, while minimum number of umbellate (4.6) was observed at control (Fig. 2b).

Number of seeds umbellate ${ }^{-1}$ significantly varied by $\mathrm{P}$ and PSB treatments; however the treatments interaction was found nonsignificant. Concerning PSB, maximum number of seeds umbellate ${ }^{-1}$ (7.8) was observed in plants treated with Phosphate solubilizing bacteria, while fewer seeds umbellate $^{-1}$ (6.0) were counted in without PSB (Fig. 1b). Regarding $\mathrm{P}$ levels, more number of seeds umbellate ${ }^{-1}$ (8.3) was counted in plants fertilized with P @ $40 \mathrm{~kg}$ $\mathrm{ha}^{-1}$, while less number of seeds (5.0) was counted at control (Fig. 2b).

The analysis of the data for seed yield plant ${ }^{-}$ ${ }^{1}$ also showed a significant response of $\mathrm{P}$ and PSB. In this case the maximum seed yield plant $^{-1}(8.3 \mathrm{~g})$ was observed in plants treated with Phosphate solubilizing bacteria and minimum yield (7.8 g) was obtained in without PSB (Fig. 1b). Among P levels, maximum seed yield plant $^{-1}(9.1 \mathrm{~g})$ was observed with the application of $40 \mathrm{~kg} \mathrm{P}^{-}$ 1 , while minimum seed yield plant $^{-1}(6.9 \mathrm{~g})$ was recorded at control (Fig. 2b). The interaction between phosphate solubilizing bacteria and phosphorus was significant. Maximum seed yield $(9.2 \mathrm{~g})$ was obtained with P application @ $40 \mathrm{~kg} \mathrm{ha}^{-1}$ along with PSB treatment, while minimum seed yield $(6.8 \mathrm{~g})$ was found in without PSB treatment at control (Fig. 3b).

Mean square values of 1000 seed weight (Table 2) showed significant response of $P$ and PSB towards 1000 seed weight in coriander. The maximum 1000 seed weight $(10.3 \mathrm{~g})$ was totaled with phosphate solubilizing bacteria, while minimum weight $(9.7 \mathrm{~g})$ was noticed in absence of PSB (Fig. 1c). For levels of $\mathrm{P}$, maximum 1000 seed weight $(11.4 \mathrm{~g})$ was recorded in plants supplied with $40 \mathrm{~kg} \mathrm{P} \mathrm{ha-1}$, while minimum 1000 seed weight $(9.0 \mathrm{~g})$ was observed at control (Fig. 2c). 
Seed yield $\mathrm{ha}^{-1}$ was varied positively by the treatments (Table 2), means related to PSB revealed that maximum seed yield $\mathrm{ha}^{-1}$ in coriander $(1105 \mathrm{~kg})$ was examined with phosphate solubilizing bacteria, while minimum yield $(1039 \mathrm{~kg})$ was noted in the absence of PSB (Fig. 1d). Comparing means showed that maximum yield $\mathrm{ha}^{-1}$ $(1212 \mathrm{~kg})$ was noticed in plants fertilized with $40 \mathrm{~kg} \mathrm{P} \mathrm{ha}{ }^{-1}$, while minimum seed yield $(923 \mathrm{~kg}$ ) was observed at control (Fig. 2d). Phosphorus and PSB showed significant effect towards seed yield $\mathrm{ha}^{-1}$ in coriander. Maximum yield $(1230 \mathrm{~kg})$ was observed with application of P @ $40 \mathrm{~kg} \mathrm{ha}^{-}$ 1 along PSB treatment. On contrary, minimum seed yield $\mathrm{ha}^{-1}(905 \mathrm{~kg})$ was found at control in without PSB plots (Fig. 3c).

Phosphorus is a main part of many macromolecules like phospholipids, nucleic acids, certain coenzymes and amino acids. Phosphorus helps in energy transfer through pyrophosphate bond in ATP. It also provides certain amount of metabolic energy in photosynthesis and respiration due to attachment of phosphate group to different sugars. This energy is utilized in the production of photosynthates and to absorb higher amount of essential nutrients from the soil. [24] Reported that optimum dose of NPK application to coriander plants resulted in more number of umbellate Umbel $^{-1}$. Similarly [15] also reported that PSB alone has a significant effect on number of umbellate umbel $^{-1}$. [25] Noted a positive impact of PSB on number of umbellate in his experiment on response of coriander to integrated nutrient management.

Plants produce vigorous growth and more number of branches under the influence of PSB, which results in increased number of flowers and seeds [26]. [21] Reported that seed number umbellate ${ }^{-1}$ was more with the use of phosphate solubilizing microorganism in Anise. [13] While investigating the response of coriander to phosphorus levels and row spacing found that maximum seed yield plant $^{-1}$ was obtained with the application of $45 \mathrm{~kg} \mathrm{P}^{-} \mathrm{ha}^{-}$ 1 . These results are also in agreement with those of [27] who stated that bio fertilizers significantly increase seed yield plant $^{-1}$ in coriander. In the presence of phosphate solubilizing microbes, plants can efficiently uptake plant nutrients especially phosphorus due to enhanced root growth. Phosphorus is an important constituent of phytin, a main storage form of phosphorus in seeds. Phytin helps increasing seed size and weight, ultimately increasing seed yield. Phosphorus also helps in root development, flower initiation, and development of seeds. Insufficient supply of Phosphorus to the plants can reduce seed size, number, and seed viability.

[25] Investigated the effect of nutrients and bio fertilizer on coriander and found that PSB has improved 1000 seed weight than in rest of the treatments. Higher crop growth and yield was examined in a variety of crops applied with PSB treatment along with $50 \%$ of suggested dosage of synthetic fertilizers [28]. These results stood at par with that of [29] who found that phosphorus and nitrogen positively influenced 500 seed weight with higher doses than in control. Phosphate solubilizing bacteria release certain acids like lactic, citric and glycolic acid and lower the $\mathrm{PH}$ of the soils thus, releasing orthophosphate ions. Phosphorus has an important role in seed quality and development, so these orthophosphate ions are readily taken up by the plants and then efficiently utilized to produce larger seeds of better quality [10]. 


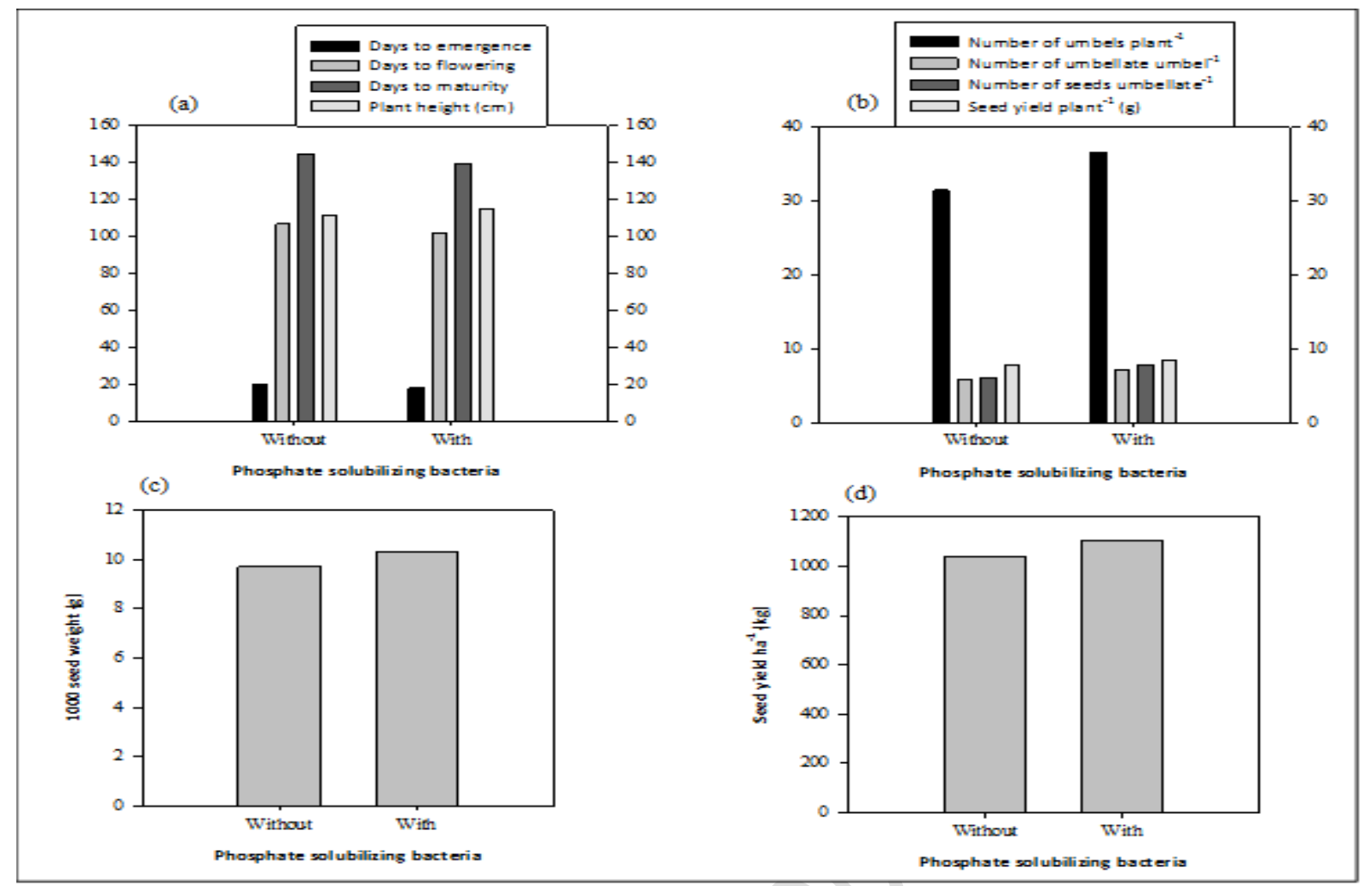

Figure 1. The Influence of Phosphate solubilizing bacteria on growth and seedproduction in coriander

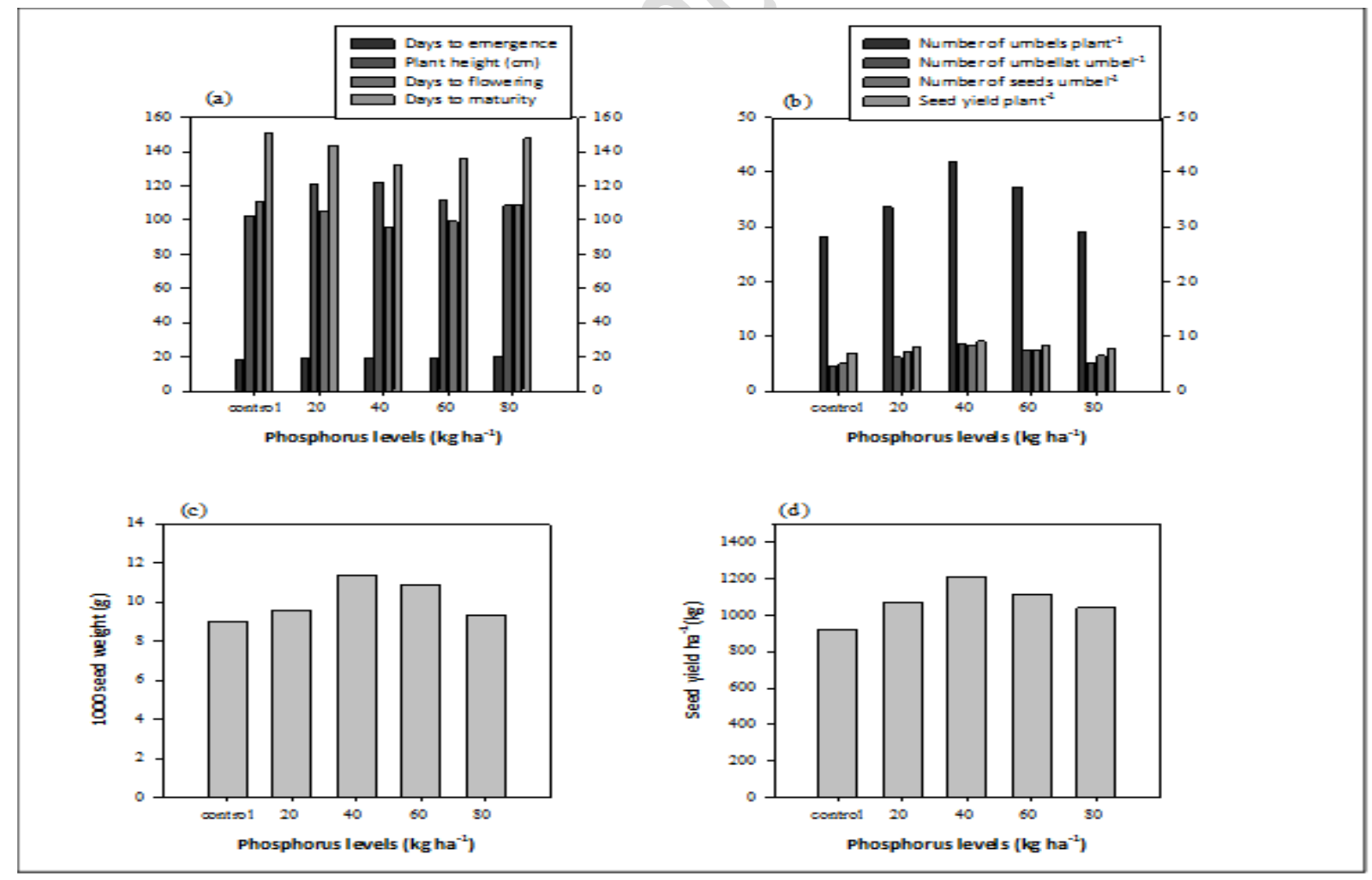

Figure 2. The effect of different Phosphorus levels on growth and seed production in coriander 


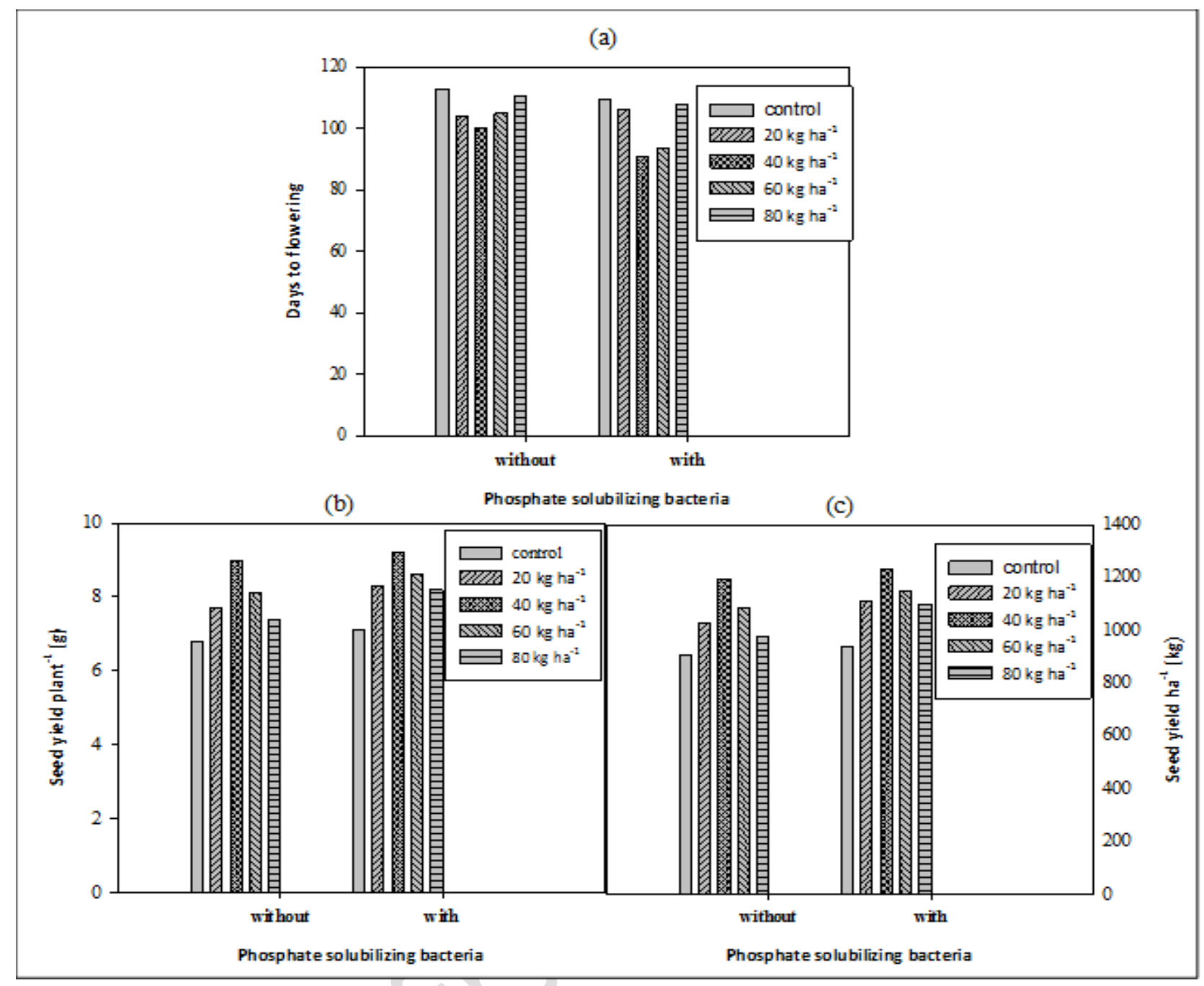

Figure 3. The interactive effect of Phosphate Solublizing bacteria and Phosphorus fertilizer on coriander

Pseudomonas specie positively influences diameter of xylem vessels and thickness of phloem tissue, vascular bundle width and ensuring higher amount of phosphorus uptake for heavier seeds [30]. Tandon [31] examined that PSB caused 10-15\% increase in crop yield. Phosphatic bio fertilizer promoted seed yield through the enhancement of yield attributes. These results are in agreement with the investigation of [32] who found positive response of PSB on grain yield of wheat. Phosphorus being a secondary macronutrient is involved in many plant functions like seed formation and development. It is stored as phytin in seeds of mature plants, which increase size and weight of the seeds. Phosphorus enhances plant metabolic pathways for better growth and yield by accelerating plant enzymatic activity. Phosphorus was also found to increase number of umbel plant ${ }^{-1}$, number of umbellate umbel $^{-1}$, seed number umbellate $^{-1}$, seed yield plant $^{-1}$ and 1000 seed weight, thus resulting an obvious increase in seed yield hectare ${ }^{-1}$.

Yield $\mathrm{kg} \mathrm{ha}^{-1}=\frac{\text { seed yield } / \text { plot }}{\text { Harvested Area }} \times 10000$

\section{Conclusion and Recommendation}

The current study revealed that various levels of phosphorus and phosphate solubilizing bacteria had significant effect on coriander growth and seed yield, based on results it is concluded that phosphorus @ $40 \mathrm{~kg} \mathrm{ha}^{-1}$ along with PSB inoculation 
significantly improved all the studied parameters. In the case of interaction a nonsignificant effect was found for most of the parameters; except days to flowering, seed yield plant ${ }^{-1}$, and seed yield ha $^{-1}$. Based on conclusions, phosphorus @ $40 \mathrm{~kg} \mathrm{ha}^{-1}$ along with the application of phosphate solubilizing bacteria is recommended for better growth and seed production of coriander.

\section{Authors' contributions}

Conceived and designed the experiments: $G$ Ayub, Performed the experiments: F Idrees, Analyzed the data: F Idrees, Contributed reagents/ materials/ analysis tools: F Idrees, Wrote the paper: S Saleem.

\section{References}

1. Bhuiyan MNI, Begum $\mathbf{J} \&$ Sulatana $\mathbf{M}$ (2009). Chemical composition of leaf and seed essential oil of (Coriandrum sativum L.) from Bangladesh. Bangla $J$ Pharmacol 4: 150-153.

2. Coşkuner Y \& Karababa E (2007). Physical properties of coriander seeds (Coriandrum sativum L.). J Food Eng 80: 408-416.

3. Agricultural Statistics of Pakistan 2010-11.

https://vdocuments. mx/agriculturalstatistics-of-pakistan-2010-11.html

4. Diederichsen A (1996). Promoting conservation and use of underutilized and neglected crops. Int Plant Gen Resources Inst Rome, Italy.

5. Hussein MH \& Abdel-Aal SA (1982). Wild and honey bees as pollinators of 10 plant species in Assiut area. Egypt $Z$ Angew Entomol 93: 342-346.

6. Hnamte V, Chatterjee R \& Tania C (2013). Growth flowering fruit setting and maturity behavior of coriander (Coriandrum sativum L.) with organics including bio fertilizers and inorganics. Bioscan 8(3): 791-793.

7. Zoubiri S \& Baaliouamer A (2010). Essential oil composition of Coriandrum sativum seed cultivated in Algeria as food grains protectant. Food Chem 122: 1226-1228.
8. Kashif N (2001). Effect of NPK on growth and chemical effect on vase-life of Zinnia. MSc Thesis PMAS Arid Agri Univ Rawalpindi Pakistan, pp. 23.

9. Hewitt EJ \& Smith TA (1975). Plant mineral nutrition. Engl Univ Press London.

10. Kundu BS, Kiren N, Yadav R \& Mau $S$ (2009). Biodiversity of phosphate solubilizing bacteria in rhizosphere of chickpea, mustard and wheat grown in different regions of Haryana. India $J$ Microbiol 49(2): 120-127.

11. Gyaneshwar P, Kumar GN \& Parekh LJ (2002). Effect of buffering on the phosphate solubilizing ability of microorganisms. World J Microbiol Biotech 14: 669-673.

12. Mallanagouda BG, Sulikeri GS, Hulamani NC, Murthy BG \& Madalgeri BB (1995). Effect of NPK and FYM on growth parameter of onion, garlic and coriander. Cur Res Univ Agric Sci Bangalore 24(11): 212213.

13. Ibadullah, J, Muhammad S, Abrar HS, Abdur R, Noor HK, Fazal-i-wahid AR, Riaz A \& Hasnain A (2011). Response of seed yield of coriander to phosphorus and row spacing. Sarhad $J$ Agric 27(4).

14. Aiswath OP, Lal G, Kant K, Sharma YK, Ali SF \& Naimuddin (2012). Influence of Bio-fertilizers on growth and yield of coriander (Coriandrum sativum L.) under Typic Haplustepts. Intl J Seed Spices 2(2): 9-14.

15. Arya PS, Sagar V \& Singh SR (1999). Effect of Nitrogen, Phosphorus and Potassium on seed yield of coriander. Sci Hort 6(5): 137-139.

16. Gyaneshwar P, Naresh KG \& Parekh LJ (2012). Cloning of mineral phosphate solubilizing agents from Synechocystis. PCC Curr Sci 74: 1097-1099.

17. Abou-Aly HE \& Gomaa AO (2002). Influence of combined inoculation with diazotrophs and phosphate solubilizers on growth, yield and 
volatile oil content of coriander plants (Coriandrum sativum L.). Bul Faculty of Agr Cairo Univ 53: 93-113.

18. Kalidasu G, Sarada C \& Reddy TY (2008). Efficacy of bio fertilizers on the performance of rainfed coriander (Coriandrum sativum) in vertisols. $J$ Spices \& Aromatic Crops 17: 98-102.

19. Tilak KVBR, Ranganayahi N, Pal KN, De R, Saxena AK \& Nautiyal CS (2005). Diversity of plant growth and soil health supporting bacteria. Curr Sci 89(1): 136-150.

20. Kant S, Peng M \& Rothstein SJ (2011). Genetic regulation by NLA and miRNA827 for maintaining nitratedependent phosphate homeostasis in Arabidopsis. PLoS Genet doi: 10.1371/journal.pgen.1002021.

21. Zand A, Darzi MT \& Syed Hadi MH (2013). Effects of phosphate solubilizing microorganisms and plant density on seed yield and essential oil content of Anise (Pimpinella anisum) Middle-East J Sci Res 14(7): 940-946.

22. Nwadukwe, PO \& Chude VO (1995). Effect of nitrogen and phosphorus on the seed yield of coriander. Indian $J$ Agron 20(2): 233-235.

23. El- Yazeid AA, Abou-Aly HE, Mady MA \& Moussa SAM (2007). Enhancing Growth, Productivity and Quality of Squash Plants Using Phosphate Dissolving Microorganis ms (Bio phosphor®) Combined with Boron Foliar Spray. Res J Agric \& Biol Sci 3(4): 274-286.

24. Tomer SS, Gupta KP, Abbas M \& Nigam KB (1994). Effect of irrigation and fertility Levels on growth and yield of coriander (Coriandrum sativum L.). Indian J Agro 39(3): 442-447.
25. Tripathi ML, Singh H \& Chouhan SVS (2013). Response of coriander (Coriandrum sativum) to integrated nutrient management. Technofame 2(2): 43-46.

26. Grusak MA (2001). Plant macro- and micronutrient minerals. Encyclopedia of life sciences and Nature Publishing Group / www.els.net.

27. Rahimi AR, Mashayekhi K, Aminiand S \& Soltani E (2009). Effect of mineral vs. bio fertilizer on the growth yield and essential oil content of coriander (Coriandrum sativum L.) Med Arm Plant Sci Biotech 3(2).

28. Ranga RP, Mir HA \& Suresh D (2003) .Impact of bio fertilizer application on crop growth and yield of different crops. Proceedings of 6th Int PGPR Workshop Calicut India 218-222.

29. Vinay S, Bisen RK \& Singh V (1999). Response of nitrogen and phosphorus on seed crop of coriander. Environ \& Ecol 17(1): 238-239.

30. El-Afry MM, El-Nady MF, Belal EA \& Metwaly MMS (2012). Anatomic al studies on drought-stressed wheat plants (Triticum aestivum L.) treated with some bacterial strains. Acta Biologica Szegediensis 56(2): 165-174.

31. Tandon HL (1987). Phosphorus Research and Production in India. Fertilizer Development and Consultation Organization New Delhi pp. 160.

32. Singh S \& Kapoor KK (1999). Inoculation with phosphatesolubilizing microorganisms and a vesicular-arbuscular mycorrhizal fungus improves dry matter yield and nutrient uptake by wheat grown in a sandy soil. Biol and Fertility of Soils 28: 139-144. 